\title{
PENINGKATAN KETERAMPILAN MENULIS KARANGAN NARASI DENGAN MENGGUNAKAN MEDIA AUDIOVISUAL DAN METODE QUANTUM LEARNING
}

\author{
Muhammad Nur Ahsin \\ noor.ahsin@umk.ac.id \\ Universitas Muria Kudus
}

\begin{abstract}
The Increase in the Narrative Writing Skills Using Audiovisual Media and Method of Quantum Learning (Classroom Action Research on the students of Class XA Islamic High School TBS Kudus Academic Year 2013/2014). The aims of this research are to: (1) improve the quality of the learning process to write narrative using audiovisual media and quantum learning method XA grade student of MA (Islamic High School) Tasywiquth Thullab Salafiyyah (TBS) Kudus and (2) improving the writing narrative skills using audiovisual media and methods of quantum learning XA grade student of MA (Islamic High School) TBS. The Method used this research use qualitative research methods, in the form of Classroom Action Research. Subject of this research in Indonesian Teachers and student of Class X A a Islamic High Scholl (MA) TBS. Datta was collected by way of: observation, interviews, review of documents, and narrative writing skills test. Test the validity of using triangulation of data sources and triangulation methods. The research proces was conducted in two cycles, each consisting of four stages: (1) preparation, (2) action, (3) observation and evaluation, (4) analysis and reflection.

The results are: (1) the aplication of audiovisual media and quantum learning methods can improve the quality of learning to write narrative on the class X A Islamic High Scholl (MA) TBS Kudus, (2) the use of audiovisual media and quantum learning methods to improve the skills narrative writing in the class X A Islamic High Scholl (MA) TBS Kudus. This can be seen with the increase in studends activity, student attention to the teacher's explanations, as well as the independence of student when writing narrative. In addition, the average student who experienced complete learned from the first cycle an second cycle also incresed. the ability to write narrative essays of students increased, the average value of the first cycle 73.46, while in the second cycle increased to 80.89 .
\end{abstract}

Keywords: Writing, Narrative, Quantum Learning, Audiovisual.

\begin{abstract}
ABSTRAK
Peningkatan Keterampilan Menulis Karangan Narasi dengan Menggunakan Media Audiovisual dan Metode Quantum Learning (Penelitian Tindakan Kelas pada Siswa Kelas X-A MA TBS Kudus Tahun Pelajaran 2013/2014). Tujuan penelitian ini adalah untuk: (1) meningkatkan kualitas proses pembelajaran menulis karangan narasi dengan penggunaan media audiovisual dan metode quantum learning pada kelas X A MA Tasywiquth Thullab Salafiyyah (TBS) Kudus dan (2) meningkatkan keterampilan menulis karangan narasi dengan menggunakan
\end{abstract}

\section{Jurnal Refleksi Edukatika}

Vol. 6 No. 2 Juni 2016 
menggunakan media audiovisual dan metode quantum learning siswa kelas X A MA TBS Kudus.

Metode yang digunakan penelitian ini menggunakan metode penelitian kualitatif, dalam bentuk Penelitian Tindakan Kelas. Subjek penelitian ini Guru Bahasa Indonesia dan siswa Kelas XA MA TBS Kudus. Data dikumpulkan dengan teknik observasi, wawancara, review dokumen, dan tes menulis karangan narasi. Uji validitas penelitian ini menggunakan teknik triangulasi data dan triangulasi metode. Proses Penelitian dilakukan dalam dua siklus, masingmasing terdiri dari empat tahap: (1) persiapan, (2) tindakan, (3) observasi dan evaluasi, (4) analisis dan refleksi.

Hasilnya adalah: (1) Penggunaan media audiovisual dan metode pembelajaran quantum learning dapat meningkatkan kualitas proses pembelajaran menulis narasi pada siswa kelas XA MATBS Kudus, (2) penggunaan media audiovisual dan metode quantum learning dapat meningkatkan keterampilan menulis narasi di kelas XA MA TBS Kudus. Hal ini dapat dilihat dengan peningkatan keaktifan siswa, minat siswa dalam pembelajaran meningkat, serta kemandirian siswa meningkat saat menulis narasi. Selain itu, nilai rata-rata siswa juga terbukti mengalami peningkatan dari siklus pertama ke siklus. Kemampuan untuk menulis karangan narasi siswa meningkat, nilai rata-rata siklus I 73,46, sedangkan pada siklus II meningkat menjadi 80,89 .

Kata kunci: Menulis, Narasi, Quantum Learning, Audiovisual.

\section{PENDAHULUAN}

Ada beberapa aspek keterampilan berbahasa Indonesia di sekolah yang harus dikuasai siswa. Menurut Tarigan (1994:2) keterampilan berbahasa mencakup empat segi, yaitu menyimak, berbicara, membaca, dan menulis. Salah satu keterampilan menulis yang harus dikuasai siswa adalah keterampilan menulis narasi.

Narasi merupakan sebuah karya yang didalamnya terkandung berbagai aspek tentang rangkaian cerita yang membentuk makna. Seorang pembaca cerita narasi kebanyakan akan terinspirasi dari sifat maupun kehidupan tokoh yang ia baca. Tidak sedikit dari mereka juga akan meniru kehidupan maupun sikap tokoh yang mereka kagumi dalam sebuah narasi. Menulis narasi bisa berdasarkan pengalaman. Pengalaman mencakupi pengalaman fisik dan pengalaman nonfisik (Nuryatin, 2010).

Melalui kegiatan menulis seseorang dapat menuangkan pikiran, ide, maupun perasaannya dalam bentuk tulisan. Untuk dapat menulis sebuah narasi dengan baik maka seorang penulis harus memiliki pengetahuan tentang narasi secara mendalam. Peningkatan pembelajaran, seperti menulis harus ditingkatkan seperti dengan penelitian tindakan kelas (PTK).

Tindakan yang dilakukan dalam rangka PTK harus diterapkan sedemikian rupa sehingga masih ada dalam batas-batas kemampuan guru serta dukungan fasilitas yang tersedia di sekolah maupun kemampuan rata-rata siswa untuk mencernanya. Dengan kata lain, sebagai aktor PTK, guru hendaknya cukup realistis dalam menghadapi kenyataan keseharian dunia sekolah tempat ia berada dan melaksanakan tugasnya (Suwandi, 2011:38).

Ketika dilakukan observasi ke beberapa sekolah di kabupaten Kudus, salah satunya di Madrasah Aliyah Tasywiquth Thullab Salafiyyah (TBS) Kudus, guru bahasa Indonesia menyatakan bahwa banyak permasalahan pembelajaran yang sering dialami siswa. Diantara berbagai masalah pembelajaran siswa kelas $\mathrm{X}$ semester gasal dalam pelajaran bahasa Indonesia adalah siswa masih merasa kesulitan ketika diberi 
tugas untuk membuat atau menulis narasi. Masalah lainnya adalah banyak siswa merasa pembelajaran menulis terasa membosankan dan kurang memanfaatkan media pembelajaran yang menarik.

Saat peneliti mewawancarai beberapa murid, diantaranya mereka mengatakan bahwa banyak siswa masih kesulitan dalam pembelajaran menulis narasi. Kegiatan pembelajaran yang dilakukan pun belum menarik. Siswa kurang antusias karena jarang menggunakan media pembelejaran yang menarik.

Berdasarkan observasi banyak siswa mengatakan susah jika diberi tugas untuk mengarang narasi. Bukti-buktinya bisa dilihat dari hasil karya narasi siswa yang cenderung asal-asalan. Hasilnya cenderung belum memuaskan. Cara menyajikan sebuah cerita juga belum menarik. Tulisan belum padu. Seperti salah satu contoh kutipan hasil narasi karya siswa berikut ini, "Rudi berjalan dalam waktu yang membosankan. Pikirannya tidak enak dan cenderung lelah." Contoh penggalan kata tersebut adalah salah satu kalimat yang tidak padu dan membingungkan.

Untuk mengatasi hal tersebut, dalam upaya memperbaiki keterampilan pembelajaran menulis narasi dan meningkatkan kompetensi dasar menulis narasi, maka kiranya perlu variasi media pembelajaran untuk meningkatkan kemampuan pemahaman siswa dalam meningkatkan kemampuan menulis narasi. Untuk itu, penulis merasa terpanggil untuk melakukan penelitian tindakan kelas mengenai pembelajaran menulis narasi.

Peneliti tertarik untuk melakukan penelitian untuk meningkatkan kemampuan menulis narasi dengan menggunakan media audiovisual dan menerapkan metode Quantum Learning kepada siswa kelas X di Madrasah Aliyah (MA) Tasywiquth Thullab Salafiyyah (TBS) Kudus.

Untuk meningkatkan keterampilam menulis narasi, maka perlu dilakukan sebuah pembaruan dalam pembelajaran menulis narasi. Salah satu pembaruan tersebut adalah dengan mengajarkan narasi menggunakan media audiovisual dan metode quatum learning.

Berdasar latar belakang tersebut di atas, peneliti merasa perlu mengadakan penelitian tindakan kelas untuk meningkatkan kemampuan menulis karangan narasi dengan menggunakan media audiovisual dan metode Quantum Learning pada Siswa kelas X-A MA TBS Kudus tahun ajaran 2013/2014.

Berdasarkan latar belakang di atas, maka masalah penelitian ini dapat dirumuskan sebagai berikut: Apakah penggunaan media audiovisual dan metode Quantum Learning dapat meningkatkan kualitas proses pembelajaran menulis narasi siswa kelas X A MA Tasywiquth Thullab Salafiyyah (TBS) Kudus?

Apakah penggunaan media audiovisual dan metode Quantum Learning dapat meningkatkan keterampilan menulis narasi siswa kelas X A MA Tasywiquth Thullab Salafiyyah (TBS) Kudus?

Tujuan diadakannya penelitian tindakan kelas ini adalah meningkatkan kualitas proses pembelajaran menulis narasi siswa dengan penggunaan media audiovisual dan metode Quantum Learning pada siswa kelas X A MA TBS Kudus.

Meningkatkan kualitas hasil keterampilan menulis narasi siswa dengan media audiovisual dan metode Quantum Learning pada siswa kelas X A MA TBS Kudus.

Narasi merupakan salah satu bentuk karangan yang diterapkan dalam proses pembelajaran yaitu dalam pelajaran bahasa Indonesia. Gorys Keraf (2001: 136) mengungkapkan bahwa narasi dapat dibatasi sebagai suatu bentuk wacana yang sasaran utamanya adalah tindak tanduk yang dijalin dan dirangkaikan menjadi sebuah peristiwa yang terjadi dalam suatu waktu.

\section{Jurnal Refleksi Edukatika}


Menurut Semi (1990: 32) narasi merupakan bentuk percakapan atau tulisan yang bertujuan menyampaikan atau menceritakan rangkaian peristiwa atau pengalaman manusia berdasarkan perkembangan dari waktu ke waktu. Atau dapat juga dirumuskan dengan cara lain: narasi adalah suatu bentuk wacana yang berusaha menggambarkan dengan sejelasjelasnya kepada pembaca suatu peristiwa yang telah terjadi berdasarkan urutan waktu. Hal ini berarti bahwa dalam menulis narasi yang perlu menjadi perhatian utama adalah urutan waktu dari sebuah wacana tersebut.

Bart N. Green, Claire D. Johnson, dan Alan Adams (2006:1) yang menyatakan bahwa step by step instructions for how to conduct and write a narrative overview utilizing $a$ 'best-evidence synthesis' approach are discussed, starting with appropriate preparatory work and ending with how to create proper illustrations (Petunjuk untuk menulis narasi dengan memanfaatkan bukti sintesis terbaik, membahas pendekatan, dimulai dengan pekerjaan yang sesuai dan berakhir dengan cara yang tepat untuk membuat ilustrasi).

Selanjutnya Bobby DePorter (2006), mengembangkan strategi pembelajaran Kuantum melalui istilah TANDUR, yaitu: a) Tumbuhkan, yaitu dengan memberikan apersepsi yang cukup sehingga sejak awal kegiatan siswa telah termotivasi untuk belajar dan memahami Apa Manfaatnya Bagiku (AMBAK). b) Alami, berikan pengalaman nyata kepada setiap siswa untuk mencoba. c) Namai, sediakan kata kunci, konsep, model, rumus, strategi dan metode lainnya. d) Demonstrasikan, sediakan kesempatan kepada siswa untuk menunjukkan kemampuannya. e) Ulangi, beri kesempatan untuk mengulangi apa yang telah dipelajarinya. f) Rayakan, dimaksudkan sebagai respon pengakuan yang proporsional.

Menurut Janzen (2011) The quantum perspective of learning environments often consist of virtual classrooms that can be designed to accommodate the quantum learner. The virtual classroom has the potential to merge virtuality and temporality with several advantages

Berdasarkan beberapa pendapat di atas disimpulkan bahwa quantum learning merupakan strategi atau method pembelajaran yang membuat siswa menyenangkan dan memotivasi siswa dalam belajar.

Djamarah dan Zain (2002:141) menjelaskan bahwa media audiovisual adalah media yang mempunyai unsur gambar dan unsur suara. Media audiovisual juga merupakan media pembelajaran yang pemakaiannya dilakukan dengan cara diproyeksikan melaui arus listrik dalam bentuk suara dan media yang diproyeksikan ke layar monitor dalam bentuk gambar dan suara. Media ini dapat menambah minat siswa dalam belajar karena siswa dapat menyimak sekaligus melihat gambar. Senada dengan di atas:

Youming Wang (2009) menyatakan, "Audiovisual aids are the most effective means of making clear the meaning of the film or the text such as language points and cultures and so on. They also provide an excellent stimulus for oral work and strengthen the students'abilities to communicate in English. Visual forms make important events in students' lives. The color, shape and arrangement of objects in stories and in ads have a profound effect on behavior. Visual forms can shape and express the feelings of people of all cultures. Visual aids make it possible to provide the students with adequate information for answering questions without recourse to his native language. Teachers should help students become aware of the many ways."

Sebagai rujukan, beberapa penelitian yang dijadikan tinjauan penelitian yang relevan diantaranya adalah penelitian Andayani (2008) dan Elen Inderasari (2009). 
Andayani (2008) dalam disertasinya yang berjudul "Pengembangan Model Pembelajaran Apresiasi Sastra berbasis Quantum Learning di Sekolah Dasar." Hasil penelitian tersebut membahas tentang pengembangan pembelajaran Apresiasi sastra, salah satunya menulis karangan narasi. Hasil penelitian menunjukkan bahwa penerapan quantum learning sangat bagus untuk pembelajaran Apresiasi sastra, termasuk menulis karangan narasi.

Inderasari (2009) dalam penelitian Tesisnya yang berjudul "Upaya Meningkatkan kemampuan menulis pengalaman melalui Metode Quantum Learning dalam pembelajaran Bahasa Indonesia pada Siswa kelas V SD Negeri 03 Kanigoro Kecamatan Kartoharjo Kota Madiun. Hasil penelitian tersebut membahasa tentang upaya meingkatkan kemampuan menulis pengalaman (narasi) siswa melalui quantum learning, penulis tersebut menyatakan bahwa kemampuan menulis siswa dapat ditingkatkan melaui quantum learning.

\section{METODE PENELITIAN}

Penelitian ini adalah penelitian tindakan kelas, yang bertujuan untuk meningkatkan kinerja guru serta hasil belajar siswa. Penelitian ini dilakukan di kelas tertentu untuk memperbaiki proses pembelajaran keterampilan menulis narasi yang kurang berhasil. Menurut Suwandi (2009) komponen-komponen yang tercakup dalam metode penelitian kualitatif meliputi: (a) setting penelitian, (b) subjek penelitian, (c) data dan Sumber data, (d) teknik pengumpulan data, (e) teknik pemeriksaan validitas data, (f) teknik analisis data, $(\mathrm{G})$ indikator kinerja (keberhasilan), dan (h) prosedur penelitian. Uraian berikut akan menjelaskan komponenkomponen tersebut secara singkat.

Data atau informasi yang paling penting untuk dikumpulkan dan dikaji berupa informasi tentang kemampuan siswa dalam menulis narasi, keterampilan siswa dalam menulis narasi, motivasi siswa dalam menulis narasi, serta kemampuan guru dalam menyususn rencama pembelajaran dan melaksanakan pembelajaran di kelas.

Data penelitian itu dikumpulkan dari berbagai sumber, adapun sumber data yang akan dimanfaatkan dalam penelitian ini antara lain: informasi data dari nara sumber yang terdiri dari siswa kelas $\mathrm{X}$ dan guru, tempat dan peristiwa berlangsungnya kegiatan pembelajaran bahasa Indonesia pada pokok bahasan menulis narasi dengan mennggunakan media audiovisual dan metode Quantum Learning, dan arsip atau dokumen, yang antara lain berupa kurikulum, Rencana Pelaksanaan Pembelajaran, hasil pekerjaan mengarang narasi siswa, foto kegiatan pembelajaran, tulisan yang dibuat siswa, hasil tes berupa tulisan narasi, serta hasil observasi dan wawancara kepada siswa atau guru pengampu mata pelajaran Bahasa Indonesia.

Teknik yang digunakan untuk memeriksa validitas adalah teknik triangulasi. Menurut Lexy J. Moleong (2007:330) "Triangulasi adalah teknik pemeriksaan keabsahan data yang memanfaatkan sesuatu yang lain.

Di luar data itu untuk keperluan pengecekan atau sebagai pembanding terhadap data itu". Lebih lanjut Patton St.Y. Slamet dan Suwarto (2007: 54) menyatakan bahwa teknik triangulasi dibagi menjadi empat macam, yaitu (1) triangulasi data, (2) triangulasi peneliti, (3) triangulasi metodologis, dan (4) triangulasi teoritis.

Berdasarkan pendapat diatas, dalam penelitian ini digunakan teknik triangulasi data dan triangulasi metode.

\section{HASIL DAN PEMBAHASAN Deskripsi kondisi awal pratindakan}

Berdasarkan hasil kegiatan obeservasi kelas dan wawancara yang dilakukan peneliti terhadap para siswa dan guru mata pelajaran bahasa Indonesia, hasilnya menunjukkan 
bahwa siswa masih kurang semangat dan kurang antusias dalam mengikuti pelajaran menulis karangan narasi di kelas. Kenyataan tersebut terlihat dalam kegiatan obeservasi yang dilakukan peneliti. Di dalam kelas, saat mengikuti pelajaran menulis narasi, sikap siswa menunjukkan kurang serius dan kurang memperhatikan pelajaran dengan baik. Kondisi tersebut diperkuat dengan adanya siswa yang berbicara sendiri dengan temannnya, ada yang mengantuk, serta ada yang menyandarkan tubuh di atas meja. Berdasarkan hasil wawancara, menurut siswa pembelajaran menulis narasi yang sudah dilakukan dengan metode ceramah kurang menarik dan kurang menyenangkan. Para siswa juga masih mengalami kesulitan dalam membuat tulisan narasi yang baik.

\section{A. Kualitas Proses}

1. Hasil observasi siklus I

Peningkatan kualitas proses pembelajaran menulis karangan narasi dengan media audiovisual dan metode quantum learning, bisa dilihat dari faktor-faktor berikut.

Kegiatan guru

Dalam merencanakan pembelajaran siklus pertama peneliti mengamati persiapan guru sebelum melaksanakan pembelajaran. Penilaian ini mengacu pada Rencana Pelaksanaan Pembelajaran (RPP) yang dibuat guru. Diantaranya tujuan pembelajaran, bahan belajar/ materi pelajaran, Strategi/metode pelajaran, media pembelajaran, memilih sumber belajar, dan prosedur penilaian. Total skor 16. nilai 66,6 masuk dalam kategori cukup.

Tabel 1. Nilai perencanaan pembelajaran

\begin{tabular}{|l|l|c|}
\hline No & \multicolumn{1}{|c|}{ Aspek yang } & Skor \\
\hline 1. & Tujuan & 3 \\
\hline 2. & Bahan & 2 \\
\hline 3. & $\begin{array}{l}\text { Strategi/Metode } \\
\text { Pelajaran }\end{array}$ & 3 \\
\hline
\end{tabular}

\begin{tabular}{|l|l|c|}
\hline 4. & Media & 3 \\
\hline 5. & $\begin{array}{l}\text { Memilih Sumber } \\
\text { Belajar }\end{array}$ & 2 \\
\hline 6 & Menyusun Penilaian & 3 \\
\hline & Total Skor & 16 \\
\hline & Nilai & 66,6 \\
\hline
\end{tabular}

Penilaian observasi pelaksanaan pembelajaran dan guru siklus pertama yang dinilai pertama kemampuan guru dalam membuka pelajaran, kedua sikap guru dalam proses pembelajaran, ketiga, penguasaan bahan belajar oleh guru, keempat proses pembelajaran, kelima kemampuan menggunakan media pembelajaran, keenam kemampuan mengevaluasi pembelajaran, dan keenam kemampuan guru dalam menutup pembelajaran. Hasil observasi menunjukkan tatal skor pelaksanaan guru siklus 1 sebesar 21. Nilai 75 atau masuk kategori baik. Nilai pelaksanaan guru dalam pembelajaran dapat juga dilihat dalam bentuk tabel, seperti dalam pemaparan tabel berikut ini.

Tabel 2. Hasil Pelaksanaan Pembelajaran Guru Siklus I

\begin{tabular}{|l|l|c|}
\hline No & \multicolumn{1}{|c|}{ Aspek yang diamati } & Skor \\
\hline 1. & Kemampuan Membuka & 3 \\
\hline 2. & $\begin{array}{l}\text { Sikap guru dalam proses } \\
\text { pembelajaran }\end{array}$ & 3 \\
\hline 3. & $\begin{array}{l}\text { Penguasaan Materi } \\
\text { Pelajaran }\end{array}$ & 3 \\
\hline 4. & $\begin{array}{l}\text { Kegiatan Belajar } \\
\text { Mengajar (Proses) }\end{array}$ & 3 \\
\hline 5. & $\begin{array}{l}\text { Kemampuan } \\
\text { Menggunakan Media }\end{array}$ & 3 \\
\hline 6 & Evaluasi Pembelajaran & 3 \\
\hline 7. & $\begin{array}{l}\text { Kemampuan Menutup } \\
\text { Pelajaran }\end{array}$ & 3 \\
\hline & Total Skor & 21 \\
\hline & Nilai & $\begin{array}{c}21 / 28 \mathrm{x} \\
100 \% \\
=75\end{array}$ \\
\hline
\end{tabular}


Kegiatan siswa

Observasi siswa siklus pertama kualitas proses pembelajaran siswa pada siklus I yang dinilai pertama adalah (1) minat, (2) keaktifan, (3), Kerjasama, (4) Tanggungjawab. Hasil observasi menunjukkan bahwa minat siswa dalam pembelajaran sebesar $72,82 \%$, ratarata 3,6 masuk dalam kategori baik. Keaktifan siswa dalam pembelajaran sebesar 73, $85 \%$ rata-rata 3,7 masuk kriteria baik. Kerjasama antarkelompok dalam pembelajaran nilainya sebesar 74, $36 \%$ rata-rata 3,7 masuk kategori baik. Untuk tanggung jawab siswa dalam pembelajaran sebesar $64,10 \%$ rata-rata 3,2 masuk kategori cukup.

Kemampuan menulis narasi siklus I

Hasil tes menulis karangan narasi siklus pertama yang sudah mencapai ketuntasan belajar minimal nilai 75 didapat $20(51,3 \%)$ siswa, sedangkan $19 \quad(48,71 \%)$ siswa masih belum tuntas. Hasil penelitian menulis karangan narasi menunjukkan bahwa siswa yang mendapat nilai 60-64 sebanyak 1 siswa.Siswa yang mendapat nilai 65-69 sebanyak 4 siswa. Untuk siswa yang mendapat nila 70-74 total berjumlah 14 siswa. Total siswa yang tidak tuntas dalam pembelajaran atau nilainya belum memenuhi KKM sebanyak 19 siswa atau 48, $71 \%$. Siswa yang sudah memenuhi KKM sebanyak 20 siswaatau $(51,3 \%)$, dengan rincian siswa yang mendapat nilai 75-79 sebanyak 10 siswa atau $25,64 \%$. Siswa yang mendapat nilai $80-84$ sebanyak 7 siswa. Siswa yang mendapat nilai 85- 89 sebanyak 3 siswa.

Tabel 3. Distribusi Frekuensi Hasil Menulis Karangan Narasi Siklus I

\begin{tabular}{|c|c|c|c|c|}
\hline No & Kelas Interval & Frekuensi (f) & Persentase & Kategori \\
\hline 1 & $60-64$ & 1 & $2,59 \%$ & Tidak tuntas \\
\hline 2 & $65-69$ & 4 & $10,26 \%$ & Tidak tuntas \\
\hline 3 & $70-74$ & 14 & $35,90 \%$ & Tidak tuntas \\
\hline 4 & $75-79$ & 10 & $25,64 \%$ & Tuntas \\
\hline 5 & $80-84$ & 7 & $17,95 \%$ & Tuntas \\
\hline 6 & $85-89$ & 3 & $7,69 \%$ & Tuntas \\
\hline & Total & & 100 & \\
\hline & Rata-rata & & $73,46 \%$ & \\
\hline
\end{tabular}

Berdasarkan tabel distribusi frekuensi penilaian hasil kemampuan menulis narasi siswa pada siklus 1 yang ditampilan pada tabel tersebut dapat disajikan dalam bentuk grafik histogram nilai kemampuan menulis karangan narasi berikut ini. Sehubungan dengan hal tersebut, hasil kemampuan menulis karangan narasi yang tuntas KMM belum $75 \%$. Maka peneliti berusaha untuk meningkatkan kemampuan siswa dalam menulis narasi dengan mengadakan penelitian tindakan kelas di kelas siklus selanjutnya atau siklus II pada siswa kelas X A MA TBS Kudus dengan menggunakanan media audiovisual dan metode quantum learning. Hal itu bertujuan untuk membantu siswa yang masih memiliki kemampuan menulis yang masih rendah, selain itu agar lebih meningkatkan kualitas proses pembelajaran menulis narasi

\section{Jurnal Refleksi Edukatika}




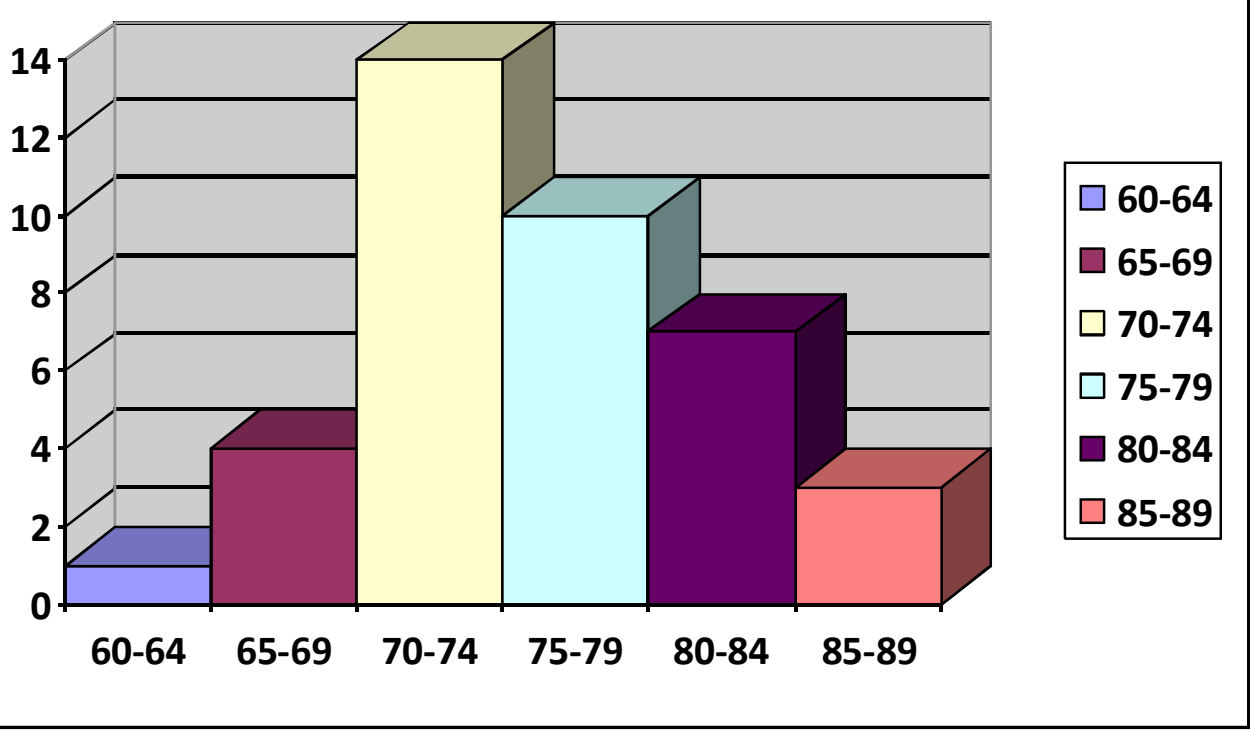

2. Hasil observasi siklus II

\section{Kegiatan guru}

Dalam merencanakan pembelajaran siklus II peneliti mengamati persiapan guru sebelum melaksanakan pembelajaran. Penilaian ini mengacu pada Rencana Pelaksanaan Pembelajaran (RPP) yang dibuat guru. Diantaranya tujuan pembelajaran, persiapan bahan belaja atau mater pelajaran, Strategi atau metode pelajaran yang digunakan, media pembelajaran, memilih sumber belajar, dan prosedur penilaian. Total skor perencanaan siklus II sebesar 20, dengan nilai 83,3 masuk dalam kategori baik.

Tabel 4. Nilai Perencanaan Pembelajaran Guru Siklus II

\begin{tabular}{|l|l|c|}
\hline No & Aspek yang diamati & Skor \\
\hline 1. & Tujuan Pembelajaran & 4 \\
\hline 2. & Bahan belajar/Materi & 3 \\
\hline 3. & Strategi/Metode & 3 \\
\hline 4. & Media Pembelajaran & 4 \\
\hline 5. & Memilih Sumber & 3 \\
\hline 6 & Menyusun Penilaian & 3 \\
\hline & Total Skor & 20 \\
\hline & Nilai & 83,33 \\
\hline
\end{tabular}

Penilaian obeservasi pelaksanaan pembelajaran guru siklus II yang dinilai pertama kemampuan guru dalam membuka pelajaran, kedua sikap guru dalam proses pembelajaran, ketiga, penguasaan bahan belajar oleh guru, keempat proses pembelajaran, kelima kemampuan menggunakan media pembelajaran,

Keenam kemampuan mengevaluasi pembelajaran, dan keenam kemampuan guru dalam menutup pembelajaran. Hasil observasi menunjukkan nilai pelaksanaan guru siklus II total skor sebesar 24 atau nilai 85, 71 masuk kategori sangat baik.

\begin{tabular}{|l|l|c|}
\hline No & Aspel yang diamati & Skor \\
\hline 1. & $\begin{array}{l}\text { Kemampuan } \\
\text { Membuka Pelajaran }\end{array}$ & 4 \\
\hline 2. & $\begin{array}{l}\text { Sikap guru dalam } \\
\text { proses pembelajaran }\end{array}$ & 3 \\
\hline 3. & $\begin{array}{l}\text { Penguasaan Materi } \\
\text { Pelajaran }\end{array}$ & 3 \\
\hline 4. & $\begin{array}{l}\text { Kegiatan Belajar } \\
\text { Mengajar (Proses) }\end{array}$ & 4 \\
\hline
\end{tabular}




\begin{tabular}{|l|l|c|}
\hline 5. & $\begin{array}{l}\text { Kemampuan } \\
\text { Menggunakan Media }\end{array}$ & 4 \\
\hline 6 & Evaluasi Pembelajaran & 3 \\
\hline 7. & $\begin{array}{l}\text { Kemampuan Menutup } \\
\text { Pelajaran }\end{array}$ & 3 \\
\hline & Total Skor & 24 \\
\hline & Nilai & $24 / 28 \mathrm{x}$ \\
\hline
\end{tabular}

\section{Kegiatan Siswa}

Pelaksanaan tindakan siklus II pertemuan kedua

Berdasarkan pengamatan analisis penulis, proses pembelajaran menulis karangan narasi siklus II menggunakan media audiovisual Garuda di Dadaku dan penerapan metode quantum learning siklus II yang dilaksanakan di ruang multimedia hasilnya sangat bagus. Pelaksanaan dilaksanakan pada Kamis, 19 September 2013 (pertemuan pertama) dan Senin, 23 September (pertemuan kedua) secara umum berjalan dengan lancar sesuai rencana. Siswa kelas X A lebih bersemangat dan antusias dalam mengikuti pembelajaran. Secara umum proses belajar mengajar yang telah dilakukan dapat diambil

kesimpulan sebagai berikut

Tabel 6. Distribusi Frekuensi Hasil Menulis Karangan Narasi siklus II

\begin{tabular}{|c|c|c|c|c|}
\hline \multicolumn{1}{|l|}{ No } & Kelas Interval & Frekuensi (f) & Persentase & Kategori \\
\hline 1 & $70-74$ & 5 & 12.83 & Belum Tuntas \\
\hline 2 & $75-79$ & 2 & 5.13 & Tuntas \\
\hline 3 & $80-84$ & 14 & 35.90 & Tuntas \\
\hline 4 & $85-89$ & 17 & 43.59 & Tuntas \\
\hline 5 & $90-94$ & 1 & 2.56 & Tuntas \\
\hline & Total & 39 & $100 \%$ & \\
\hline & Rata-rata & 80,89 & & \\
\hline
\end{tabular}

Pada siklus II guru kolaborator yang mengajar sudah menggunakan media audiovisual dan sudah mampu menerapkan metode quantum learning dalam pembelajaran menulis karangan narasi berdasarkan pengalaman orang lain. Dengan pemanfaatan media dan prosedur TANDUR, hasil pembelajaran lebih menyenangkan dan hasilnya memuaskan.

Siswa lebih aktif dalam pembelajaran di kelas dan lebih antusias mengikuti pembelajaran. Sikap siswa menunjukkan suka dengan metode pembelajaran yang disampaikan guru. Dalam pelaksanaan siklus II siswa kelas X A yang antusias menjawab soal-soal (baik lisan maupun tulisan) sebanyak $33(82,5 \%)$ siswa, sedangkan lainnya sebanyak $7(17,5 \%)$ siswa lainnya diam saja dan tidak angkat tangan saat diberi pertanyaan lisan oleh guru. Peningkatan keaktifan siswa dalam pembelajaran di kelas merupakan hasil dari guru memberikan reward berupa pujian yang memotivasi: seperti ucapan, tepat sekali, bagus sekali, sangat tepat, kamu pintar dan juga reward berupa hadia perlengkapan alat tulis dan minuman botol kepada siswa yang aktif, sehingga siswa terlihat antusias sekali. Siswa yang aktif selama pemberian apersepsi sebanyak $9(23,07 \%)$ siswa, sedangkan 30

\section{Jurnal Refleksi Edukatika}


$(76,03)$ siswa kurang aktif dan cenderung diam saja melihat teman-temannya yang lain.

Dalam proses pembelajaran siswa kelas $\mathrm{X}$ A yang aktif selama kegiatan belajar mengajar (KBM) berlangsung yaitu sebanyak 11 siswa. Sedangkan siswa yang aktif dalam kegiatan Tanya jawab 13 siswa yang aktif.

Peningkatan minat dan keaktifan itu karena penggunaan media audiovisual sesuai dengan teori Djamarah dan Zain (2002:141) menjelaskan bahwa media audiovisual adalah media yang mempunyai unsur gambar dan unsur suara. Media audiovisual juga merupakan media pembelajaran yang pemakaiannya dilakukan dengan cara diproyeksikan melaui arus listrik dalam bentuk suara dan media yang diproyeksikan ke layar monitor dalam bentuk gambar dan suara. Media ini dapat menambah minat siswa dalam belajar karena siswa dapat menyimak sekaligus melihat gambar. Dengan media audiovisual selain meningkatkan minat juga meningkatkan hasil pembelajaran.

B. Hasil Menulis narasi Siklus II

Hasil penelitian 34 siswa tuntas dan sebanyak 5 siswa belum tuntas KKM. Hasil penelitian menulis karangan narasi siklus II menunjukkan bahwa siswa yang mendapat nilai 70-74 sebanyak 5 siswa. Siswa yang mendapat nilai 75-79 sebanyak 2 siswa.

Siswa yang mendapat nilai $80-84$ total berjumlah 14 siswa. Siswa yang mendapat nilai $85-89$ berjumlah 17 siswa. Siswa yang mendapat nilai 90-94 berjumlah 1 siswa. Total siswa yang belum memenuhi KKM sebanyak 5 siswa atau 12, 83\%. Siswa yang sudah memenuhi KKM sebanyak 34 siswa atau $(87,17 \%)$.

Berdasarkan hasil pekerjaan siswa dalam menulis karangan narasi didapat bahwa capaian nilai siswa yang sudah memenuhi KKM 75 diperoleh $34(87,17 \%)$ siswa yang sudah menulis dengan baik dan memuaskan. Sedangkan sebanyak 5 (12,83\%) siswa sisanya masih perlu dilakukan perbaikan. Jumlah siswa yang sudah memenuhi nilai KKM sudah ada lebih dari $75 \%$.

Jadi penelitian sampai siklus II dianggap cukup dan sudah memenuhi target.

Berdasarkan hasil analisis dan refleksi pelaksanaan pembelajaran di atas, tindakan siklus II sudah bisa dikatakan berhasil maksimal secara keseluruhan. Peningkatan terjadi pada beberapa indikator jika dibandingkan dengan siklus I. Nilai rata-rata siswa kelas $\mathrm{X}$ A sudah mencapai batas ketuntasan sebanyak 80,89\% siswa, meskipun ada beberapa siswa sebanyak $12,73 \%$ yang belum mencapai nilai di atas KKM. Perbandingan rata-rata hasil pekerjaan siswa siklus I, $(73,46 \%)$ dan siklus II (80,89\%).

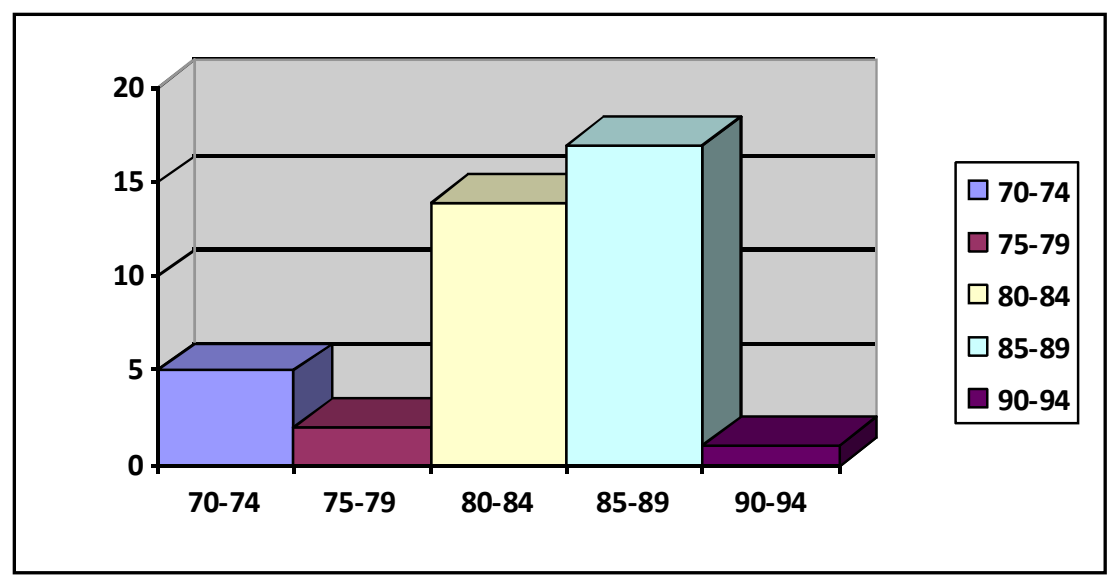

Gambar 2. Grafik Nilai Kemampuan Menulis Narasi siklus II 
Hasil pelaksanaan pembelajaran kemampuan menulis karangan narasi dengan media audiovisual dan penerapan metode quantum learning, ternyata sangat mampu meningkatkan kualitas proses pembelajaran siswa dan mampu meningkatkan kemampuan menulis karangan narasi siswa. Jadi terbukti bahwa media audiovisual dan penerapan metode quantum learning dapat membuat pembelajaran lebih bermakna, siswa lebih antusias, lebih aktif, dan hasil menulis karangan narasi siswa meningkat.

Pemakaian media untuk pembelajaran seperti media audiovisual terbukti efektid meningkatkan kualitas proses dan hasil pembelajaran seperti pernyataan (Hamalik, 1994) yang menyatakan bahwa Media pendidikan adalah alat, metode, dan teknik yang digunakan dalam rangka mengefektifkan komunikasi dan interaksi antara guru dan siswa dalam proses pendidikan dan pengajaran di sekolah. Berdasarkan terori tersebut media jelas terbukti dapat meningkatkan kualitas pembelajaran.

\section{Hasil Pembahasan}

1. Terjadi Peningkatan Kualitas Proses Pembelajaran Menulis Karangan Narasi dengan Media Audiovisual dan Metode Quantum Learning

Berdasarkan hasil pengamatan yang dilakukan peneliti selama proses pembelajaran dinyatakan bahwa terjadi peningkatan kualitas proses dan hasil pembelajaran dalam menulis karangan dengan perincian sebagai berikut.

Kualitas proses pembelajaran siswa pada siklus I yang dinilai pertama adalah (1) minat, (2) keaktifan, (3), Kerjasama, (4) Tanggung jawab. Hasil observasi menunjukkan bahwa minat siswa dalam pembelajaran sebesar $72,82 \%$, rata-rata 3,6 masuk dalam kategori baik. Keaktifan siswa dalam pembelajaran sebesar $73,85 \%$ rata-rata 3,7 masuk kriteria baik. Kerjasama antarkelompok dalam pembelajaran nilainya sebesar $74,36 \%$ rata-rata 3,7 masuk kategori baik. Untuk tanggung jawab siswa dalam pembelajaran sebesar $64,10 \%$ rata-rata 3,2 masuk kategori cukup.

Hasil penilaian proses pembelajaran siswa pada siklus II menunjukkan bahwa minat siswa dalam pembelajaran sebesar 76 , $22 \%$, rata-rata 3,8 masuk dalam kategori baik. Untuk keaktifan siswa dalam pembelajaran sebesar 78, $46 \%$ rata-rata 3,7 masuk kriteria baik. Kerjasama antarkelompok dalam pembelajaran nilainya sebesar $77,44 \%$ ratarata 3,8 masuk kategori baik. Untuk tanggung jawab siswa dalam pembelajaran sebesar 76, $41 \%$ rata-rata 3,8 masuk kategori baik. Berdasarkan data tersebut kualitas proses pembelajaran siswa dari siklus I dan siklus II meningkat.

Ketika dilakukan penelitian tindakan siklus I dengan menggunakan media audiovisual dan metode quantum learning diketahui bahwa selama pelaksanaan siklus I diketahui dari segi keaktifan apersepsi siswa kelas X A masih menunjukkan rendah yaitu sekitar 7 anak, sedangkan siswa yang aktif selama KBM sebanyak 6. Sedangkan siswa yang aktif dalam menjawab berbagai pertanyaan sebanyak 8 Anak. Mengenai kemampuan menulis narasi yang sudah memenuhi ketuntasan belajar sebanyak 20 anak.

Akan tetapi setelah dilakukan analisis dan refleksi antara guru dan peneliti dengan adanya perbaikan pada siklus II akhirnya bisa meningkat dengan sangat signifikan yaitu keaktifan dalam apersepsi sebanyak 9 anak. Untuk siswa yang aktif dalam kegiatan belajar mengajar (KBM) sebanyak 76\%. Siswa yang mampu menulis karangan narasi dengan baik dan tuntas sebanyak 34 anak. Berdasarkan tindakan siklus I dan siklus II tersebut, guru telah berhasil melaksanakan pembelajaran menulis karangan narasi kepada siswa dengan baik. menulis karangan narasi siswa.
a. Kualitas
Meningkat
Pada awalnya, sebelum tindakan siklus
I dan siklus II dilakukan, pada pembelajaran 
pratindakan siswa kurang aktif dan kurang antusias dalam mengikuti pelajaran bahasa Indonesia. Siswa kelihatan tidak tertarik mendengarkan guru, ada yang mengantuk dan kurang semangat. Guru dalam mengajar tidak menggunakan media pembelajaran yang menarik dan juga tidak menggunakan metode pembelajaran yang inovatif dan menyenangkan. Dalam pembelajaran guru hanya menggunakan metode ceramah mulai awal pembelajaran hingga akhir pembelajaran. Kelemahan dari metode konvensional siswa jadi kurang tertarik mengikuti pembelajaran. Kualitas proses pembelajaran pun kurang memuaskan.

Hal tersebut terlihat dari suasana kelas pada saat pembelajaran menulis karangan narasi, siswa banyak yang diam, tidak aktif, tidak berani bertanya, dan ada juga yang kelihatan ngantuk. Bahkan juga ada beberapa siswa yang tidak memerhatikan guru ketika menerangkan di depan kelas. Setelah guru menggunakan media audiovisual dan metode quantum learning dengan prosedur TANDUR dalam pembelajaran menulis karangan narasi, kualitas proses pembelajaran pun meningkat. Siswa terlihat antusias dan memperhatikan guru dalam mengajar, siswa juga makin aktif bertanya dan aktif menjawab beberapa pertanyaan dari guru. Siswa tidak ada yang ngantuk. Semua terlihat senang dan gembira dalam pembelajaran menulis karangan narasi.

b. Hasil Kemampuan Menulis Narasi Meningkat

Hasil peningkatan kemampuan menulis karangan narasi cukup bagus dan signifikan. Pada pelaksanaan siklus I, hasil kemampuan menulis karangan narasi menunjukkan, nilai tertinggi mencapai 85 diraih oleh 3 siswa. Sedangkan nilai terendah siswa adalah 65 diraih oleh 4 siswa. Sedangkan rata-rata kelas pada siklus pertama 73,46.

Setelah dilakukan tindakan siklus II nilai siswa pun meningkat cukup signifikan. Nilai tertinggi 90 diraih oleh1 siswa. Adapun nilai terendah adalah 70 diraih oleh 5 siswa. Nilai rata-rata kelas meningkat menjadi 80,89.

Berdasarkan hasil tersebut, nilai ratarata siklus I sebesar 73, 46 pada siklus II meningkat menjadi 80,89 . Nilai rata-rata siswa mengalami peningkatan sebesar 7,43. Nilai terendah siklus I sebesar 60 pada siklus II sedangkan nilai tertinggi 85. Nilai terendah sikuli II sebesar 70 sedangkan nilai tertinggi 90. Hal ini menunjukkan bahwa terjadi peningkatan hasil kemampuan narasi dari siklus I ke siklus II. Data dari tabel tersebut mengenai hasil peningkatan kemampuan menulis narasi juga dapat disajikan ke dalam grafik berikut ini:

\section{KESIMPULAN}

Simpulan hasil penelitian ini hasilnya yaitu terdapat peningkatan kualitas proses pembelajaran dan hasil kemampuan menulis karangan narasi siswa.

Pertama, penggunaan media audiovisual dan penerapan metode quantum learning terbukti dapat meningkatkan kualitas proses pembelajaran menulis karangan narasi. Hal itu dapat dibuktikan dengan minat siswa siklus I sebesar 72, $82 \%$ pada siklus II meningkat menjadi 76, $92 \%$. Keaktifan siswa saat pembelajaran siklus I sebanyak 73, $85 \%$ pada siklus II meningkat menjadi 78, $46 \%$. Kerjasama kelompok siklus I sebesar 74, $36 \%$ pada siklus II meningkat menjadi 77, $46 \%$.

Kedua, penggunaan media audiovisual dan penerapan metode quantum learning terbukti dapat meningkatkan kualitas hasil kemampuan menulis karangan narasi pada siswa kelas X A MA Tasywiquth Thullab Salafiyyah (TBS) Kudus. Hal itu dapat dibuktikan nilai rata-rata siswa yang mengalamai peningkatan pada tiap siklusnya, yaitu siklus I nilai rata-ratanya sebesar 73,46 dan siklus II sebesar 80,89. Pada siklus I siswa yang sudah memenuhi KKM sebannyak $20(51,28 \%)$ siswa, sedangkan pada siklus II siswa yang memenuhi KKM sebanyak 34 $(87,17 \%)$ siswa. 
Berdasarkan dengan hasil kesimpulan di atas, peneliti dapat mengajukan sara-saran sebagai berikut ini:

1. Bagi Guru

Berdasarkan hasil penelitian, guru bahasa Indonesia di tiap sekolah disarankan untuk dapat mengajarkan pelajaran dengan menarik dan mengubah cara belajar dari metode ceramah atau konvensional dengan penggunaan media dan metode pembalajaran yang lebih inovatif.

2. Bagi Siswa

Siswa hendaknya dapat menulis karangan narasi dengan menggunakan media audiovisual dan metode quantum learning melalui prosedur TANDUR yang terbukti mampu memunculkan daya kreativitas siswa.

3. Bagi Kepala Sekolah

Kepada pihak sekolah disarankan untuk memotivasi setiap guru untuk selalu menggunakan media pembelajaran yang menarik dan juga menggunakan metode pembelajaran yang inovatif, seperti metode quantum learning agar hasil kemampuan belajar siswa lebih meningkat.

\section{DAFTAR PUSTAKA}

Andayani. 2008. "Pengembangan Model Pembelajaran Apresiasi Sastra Berbasis Quantum Learning di Sekolah Dasar." Surakarta: Disertasi Pascasarjana UNS. (Unpublisided).

Bobby, DePorter dan Mike Hernacki. 2006. Quantum Learning. Jakarta: Kaifa.

Djamarah, Syaiful B dan Zain, Aswan. 2002. Strategi Belajar Mengajar. Jakarta: Rineka Cipta.

Green,BN. Johnson,CD dan Adams, A. 2006 ."Writing Narrative Literature Reviews for Peer Reviewed Journals: Journal Journal of Chiropractic Medicine. Volume 5 (Issue) 3. Vietnam. (Dalam http://www.journalchiromed.com/article /PIIS0899346707601426/abstract).

Hamalik, Oemar. 1994. Media

Pendidikan. Bandung: Cipta Aditya

Bakti.

Inderasari, Elen. 2009. "Upaya Meningkatkan kemampuan menulis pengalaman melalui Methode Quantum Learning dalam pembelajaran Bahasa Indonesia (Penelitian Tindakan Kelas pada Siswa kelas $V$ SD Negeri 03 Kanigoro Kecamatan Kartoharjo Kota Madiun." Surakarta: Tesis Pascasarnaja UNS. (Unpublisided).

Janzen, Katherine J.. 2011. Aligning the Quantum Perspective of Learning to Instructional Design: Exploring the Seven Definitive Questions. Journal of Writing. Canada: Vol 2, No.1. Mount Royal University. (doaj.org)

Keraf, Gorys. 2001. Argumentasi dan Narasi. Jakarta: Gramedia

Moleong, Lexy J.. 2007. Metodologi Penelitian Kualitatif. Bandung: Remaja Rosdakarya.

Nuryatin, Agus. 2010. Mengabadikan Pengalaman dalam Cerpen. Rembang: Yayasan Adhigama.

Semi, M. Atar. 1990. Menulis Efektif. Padang: Angkasa Raya Padang.

Suwandi, Sarwiji. 2009. Penelitian Tindakan Kelas dan Penulisan Karya Ilmiah. Surakarta : FKIP UNS

2011. Penelitian Tindakan Kelas (PTK) dan Penulisan Karya Ilmiah. Surakarta: Yuma Pustaka. 
Slamet, St. Y. dan Suwarto. 2007.

Dasar-dasar Metodelogi Penelitian

Kualitatif.Surakarta: UNS PRESS

Tarigan, Henry Guntur. 1994. Menulis sebagai Suatu Keterampilan Berbahasa. Bandung: Angkasa.
Wang, Youming. 2009. Using Films in the Multimedia English Class. English Languange Teaching. Beijing Cina: Vol. 2, No. 1. (doaj.org). at:http://ir.lib. uwo.ca/cjsotl_rcacea/vol2/iss2/5Wibow o, Wahyu. 2001. Manajemen Bahasa. Jakarta: Gramedia Pustaka Utama. 